\title{
THE EFFECTS OF PHYSICAL RESOURCES ON AIRPORTS AND SEAPORTS DEVELOPMENT PROJECTS PERFORMANCE IN ZANZIBAR
}

\author{
Ramadhan Kh. Ramadhan', Dr Salum S. Mohamed ${ }^{2}$ \\ Faculty of Business Management, Department of Marketing and Entrepreneurship, Open University of Tanzania ${ }^{1,2}$
}

\begin{abstract}
The study aimed at examine the effects physical resource challenges facing airports and seaports development projects in Zanzibar. However, there was inadequate information on how physical resources determines the performance of airports and seaports development projects in Zanzibar. The study adopted positivism research philosophy, explanatory, and descriptive cross-sectional research designs. Also, quantitative data were collected by the use of questionnaires. The questionnaire was administered to 214 respondents all randomly drawn from the five projects selected in Zanzibar. Multiple linear regression models were used to analyse and test the hypotheses. The study found that the effect of physical resources on the performance has a positive contributed to the performance of airport and seaports development projects. The study recommends that the government should enforce and strengthen the policy on acquisition of physical resources for public development of airport and seaport projects.
\end{abstract}

Key words. Physical resources, Seaport and Airport, Development projects, Performances

\section{Background of the project}

\section{INTRODUCTION}

In Zanzibar, According to Zanzibar UNDP Report of (2015), prepared by Zanzibar Planning Commission, shows that the resources allocation and effective utilization on its development projects, leads the performance especially social services projects. The population living under the food poverty line has halved, school enrolment rates have substantially increased and there are now more girls than boys at both primary and secondary level schools. The report portrays many achievements gained from the effective implementation of financial, materials and qualified staffs on implementing development projects, in general Zanzibar has made achievement that worth celebrating, (UNDP, 2015). RGZ (2019) report portrays that the Government of Zanzibar has supported more than 63 programs and projects that are implemented in Unguja and Pemba. However, there are still some challenges on allocation and utilization of resources and particularly in the seaports and airport projects which consume large amount of money (RGZ, 2019).

Regarding development projects especially airport and seaport, Zanzibar maritime transport aims at ensuring satisfactory cargo movements in and out of Zanzibar over the medium and long-term period (RGZ, 2019). The economic future of Zanzibar requires the rapid development of modern ports and airport which are able to provide efficient long-term cargo and transport services for Zanzibar and East Africa at large.

The Unguja and Pemba existing ports have been identified as potential for a Hub Port in Zanzibar. Airports create the beautiful transport infrastructure, provide international gateways and are used as the domestic traffic to reach remote business opportunities in the country (ADB, 2016). In that way they increase the country's revenue and GDP through promoting tourism activities, transportation of cargo and passengers.

\subsection{Theoretical literature review}

\section{LITERATURE REVIEW}

The study mainly used the Resource Based Theory (RBT) which highlights importance of uniquely utilising the resources to gain the sustained competitive advantage (SCA) against the competitors. Moreover, the resource based view was supported by other theories and models, namely Project Management theory and balanced score card which also enriched the study.

Resource Based Theory was popularized in the field of management science from early 1950's based on the importance and implications of resources for the performance of firms. RBT was developed and used by a number of strategic management researchers who include Penrose (1959 \& 2003), Barney (2017), Peteraf (1993), and Mata et al. (2016).

Project management theory is a popular theory in the field of project planning and management. This theory aims at helping the project coordinators and managers to use the project resources effectively so as to have project good outcomes 


\section{International Advanced Research Journal in Science, Engineering and Technology}

Vol. 8, Issue 5, May 2021

\section{DOI: $10.17148 /$ IARJSET.2021.8507}

and manage to achieve its quality goals and objectives (Martin, 2016; PMI, 2017). The project management suggests the better ways to allocate and utilize resources to bring sustainability and performance in the projects.

A balanced score card is a performance measurement model that identifies and reports the performance measures for each key strategic area of the business. The proponents of balanced score card (BSC) contend that apart from measuring the project performance using only financial measures, non- financial metrics help the top management to assess the long run survival of an organization. Kaplan and Norton (2016) suggest a Balanced Scorecard (BSC) with four measurement perspectives that apply to all organizations regardless of their strategy. First, the financial perspective measures such as capital size, sales, revenue and profit. Second, customer perspective measures such as customer satisfaction, customer profitability, market share, and product and service attributes. Third, internal process perspective measures such as quality, process efficiency, and time. Fourth, innovation measures such as employee's satisfaction, skills development, and organizational climate for motivation. The BSC model is critical because it helps planners to identify what should be done and what can be measured.

\subsection{Empirical literature review}

In a related sense, Joseph and Olatunde (2011) looked at the provision of material resources (facilities) as it relates to the construction performance of low cost and affordable house projects in South Africa between 1990 and 1997 in Cape Town, South Africa. The results of the construction of low cost house in South Africa conducted between 1990 and 1997 in 50 districts in both rural and urban areas of the state constituted the basic data used for low cost house constructions achievement or performance. Data were analyzed using mean and t-test. The results showed that there was no significant difference in the performance of the construction of low cost house from rural and urban areas in terms of availability of construction materials like cement $(\mathrm{t}=1.79, \mathrm{p}<0.05)$, availability of gravels $(\mathrm{t}=1.20, \mathrm{p}<0.05)$ and availability of iron facilities $(\mathrm{t}=1.83, \mathrm{p}<0.05)$. The study recommended that the Government through national housing cooperation should provide adequate material resources to rural and urban dwellers to enhance better shelter and improved the urban planning(Joseph and Olatunde 2011).

Garuba (2013) reported that Zanzibar project managers and experts operate from an unconducive environment where infrastructure projects seem to be not successful performed particularly in rural areas. The major questions therefore are what physical resources are available and if available are they utilized? Thus, the major purpose of this study was to ascertain the physical resources which are available and utilized in the implementation of infrastructure projects like airport and seaport in Zanzibar.

Kadzara (2016) observed that building materials and facilities on infrastructure projects are not enough available in Zanzibar and most of them are imported from outside, and that even the available ones are not often used but kept in warehouse for long time.

Basing on theoretical and empirical review (Garuba, 2013; Joseph and Olatunde, 2011; Kadzara, 2016; Mwendapole, 2015; Wernerfelt, 1984), this study hypothesises that:

Ho. Physical resources have no significant effect on the performance of the five selected projects in Zanzibar.

Ha. Physical resources have a significant effect on the performance of the five selected projects in Zanzibar.

\subsection{Research Philosophy}

\section{RESEARCH METHODOLOGY}

This study was guided by positivism research philosophy which premises that, knowledge is based on facts obtained from objective reality and expressed numerically with explanatory and predictive power and not on subjective status of an individual's views (Furrer et al., 2018). Research based on a positivistic approach depends on testing and verification of empirical facts in order to identify the relationships between variables in a given phenomenon.

Positivism research philosophy, knowledge is only considered valid if it is based on values of reason and facts gathered through direct observations and measured empirically using quantitative methods and statistical analysis leading to development of theoretical models that can be generalizable to explain cause and affect relationships. The choice of positivistic approach for this study was ideal since the study involved collection of data and hypothesis testing using statistical techniques as recommended by Lewis and Thornhill (2017).

\subsection{Research strategy}

The study used explanatory and descriptive cross-sectional research designs where quantitative data was collected by use of questionnaire.Descriptive survey design is advantageous since it enable the researcher to obtain an accurate profile of the people, events or situations. It has flexibility of using methods of quantitative or qualitative data or both giving a researcher greater options in selecting the instrument for data gathering (Ishengoma, 2012).

\subsection{Data processing and analysis}

The quantitative methods like Regression analysis, frequency tables, and percentages, among others. The regression software packages such as SPSS, Microsoft with window version 20. The Chi-square methods were used to test three 
Vol. 8, Issue 5, May 2021

DOI: $10.17148 /$ IARJSET.2021.8507

Null hypotheses formulated in this study. The quantitative techniques are advantageous because they allow researchers to conduct a broad survey, which involves many subjects and generalization of findings.

\section{FINDINGS AND DISCUSSION}

Table 1. 0 Physical Resources Index

\begin{tabular}{|c|c|c|c|c|}
\hline Index value & Frequency & Percent & Cumulative Percent & \\
\hline 1.00 & 39 & 18.2 & 18.2 & \multirow{2}{*}{ No effects } \\
\hline 1.11 & 9 & 4.2 & 22.4 & \\
\hline 1.22 & 3 & 1.4 & 23.8 & \multirow{5}{*}{ Little effects } \\
\hline 1.33 & 3 & 1.4 & 25.2 & \\
\hline 1.44 & 3 & 1.4 & 26.6 & \\
\hline 1.67 & 3 & 1.4 & 28.0 & \\
\hline 1.78 & 3 & 1.4 & 29.4 & \\
\hline 1.89 & 3 & 1.4 & 30.8 & \multirow{7}{*}{ Moderate effects } \\
\hline 2.00 & 15 & 7.0 & 37.9 & \\
\hline 2.11 & 18 & 8.4 & 46.3 & \\
\hline 2.22 & 6 & 2.8 & 49.1 & \\
\hline 2.44 & 3 & 1.4 & 50.5 & \\
\hline 2.56 & 3 & 1.4 & 51.9 & \\
\hline 2.78 & 3 & 1.4 & 53.3 & \\
\hline 2.89 & 9 & 4.2 & 57.5 & \multirow{8}{*}{ Lager effects } \\
\hline 3.11 & 34 & 15.9 & 73.4 & \\
\hline 3.33 & 3 & 1.4 & 74.8 & \\
\hline 3.56 & 3 & 1.4 & 76.2 & \\
\hline 3.78 & 3 & 1.4 & 77.6 & \\
\hline 3.89 & 6 & 2.8 & 80.4 & \\
\hline 4.11 & 15 & 7.0 & 87.4 & \\
\hline 4.22 & 3 & 1.4 & 88.8 & \\
\hline 4.33 & 3 & 1.4 & 90.2 & \\
\hline 4.78 & 3 & 1.4 & 91.6 & \\
\hline 5.00 & 18 & 8.4 & 100.0 & \\
\hline Total & 214 & 100.0 & & \\
\hline Mean & & 2.6189 & & \\
\hline Std. Deviation & & 1.2787 & & \\
\hline Minimum & & 1.00 & & \\
\hline Maximum & & 5.00 & & \\
\hline \multirow[t]{4}{*}{ Percentiles } & 20 & 1.1111 & & \\
\hline & 40 & 2.1111 & & \\
\hline & 60 & 3.1111 & & \\
\hline & 80 & 3.8889 & & \\
\hline
\end{tabular}

Source: Survey Data (2020)

The overall aggregate score on respondents' responses regarding various issues of physical resources was 2.6189 with a standard deviation of 1.2787 .

This implies that, the issues such as availability, adequacy, functionality and maintenance in regard to physical resources are only addressed moderately by the projects management leading to moderate projects performance. The standard deviation of 1.0855 implies that the respondents' views were homogenous.

The objective sought to evaluate the effect of physical resources on enhancing performance of selected projects in Zanzibar. Null hypothesis $\left(\mathrm{H}_{0}\right)$ was formulated with assumption that there is no significant effect on physical resources on enhancing performance of selected projects in Zanzibar. The regression results indicated that the beta coefficient of physical resources was 0.537 with a P-value of 0.000 .

This implies that when other factors remain constant a unit increase in physical resources results to an increase of 0.537 in performance of selected projects in Zanzibar. Therefore, at $\mathrm{P}<0.05$ level of significance the null hypothesis $\left(\mathrm{H}_{0}\right)$ is rejected implying that physical resources have a positive statistical and significant effect on performance of selected projects in Zanzibar.

The findings of this study are consistent with Sai, et al (2012) who established that there is a significant positive relationship between availability of physical resources and performance of public health projects in Chitoor District of 


\section{International Advanced Research Journal in Science, Engineering and Technology}

Vol. 8, Issue 5, May 2021

\section{DOI: $10.17148 /$ IARJSET.2021.8507}

Andhra Pradesh in India. The finding collaborates with Dasanayaka (2010) who found that there was a significant relationship between adequacy, maintenance and quality of physical resources and performance of project in Sri Lanka. Nelson (2015) on the other hand started that if the facilities resources like machines are not available in mining and manufacturing industry in Europe the objectives and targets on performance in mining industry was not be achieved. The findings correlate with results from Igba (2015) who investigated the indispensability of agricultural input materials in the implementation of COICA rice irrigation scheme programme. The result of the study showed that agricultural input materials promote rice productions scheme in Tanzania. Thus, physical resources are important and hence have positive relationship with performance in projects.

In an unrelated sense, Joseph and Olatunde (2011) looked at the provision of material (facilities) as it relates to performance of construction of low cost and affordable house projects in South Africa between 1990 and 1997 in Cape Town, South Africa. The results showed that there was no significant difference in the performance of the construction of low cost house from rural and urban areas in terms of availability of construction materials like cement, availability of gravels and availability of iron facilities.

The study is inconsistent with Grimes (2018) who found that possession of physical resources does not automatically lead to good performance but availability of skilled technical staff that can service and maintain physical resources in order to guarantee improved performance.

This is further confirmed by Kadzara (2016), who observed that building materials and facilities on infrastructure projects are not enough available in Zanzibar and most of them are imported from outside, and that even the available ones are not often used but kept in warehouse for long time.

\section{CONCLUSION AND POLICY IMPLICATION}

The study found that there was a positive contribution of physical resources to performance of airport and seaport projects, which are two Abeid Karume international airports, Pemba airport, Wete seaports, Mkoani seaport and Malindi seaport projects. Furthermore, the study revealed that physical resources played a key role in improving performance of selected airport and seaport projects that had a positive effect on the performance of selected airport and harbor projects.

Therefore, the Zanzibar airport, Pemba airport, Malindi seaport, Mkoani seaport and Wete seaport were the central development projects to the Zanzibar's national objectives of achieving sustained economic growth and poverty reduction. The development projects were dominated and funded by central government.

The government should increase the materials resources of project, the government should increase budgetary on physical allocation of resources for the projects so as to be able to acquire the performances.

The study recommended that the Zanzibar government should enforce and strengthen on acquisition of physical resources. Further, the government should increase financial budgetary allocation for public development projects.

\section{REFERENCES}

[1]. Dye, P. \& Webster, L. (2017). A Survey of Medium and Large Private Companies in the Lao PDR, Vientiane: International Financial Corporation. World Bank Group Review.

[2]. Field, A. P. (2016). Discovering Statistics using SPSS.2nd Ed. London: Sage.

[3]. Furrer, O., Thomas, H. \& Goussevka, A. (2018). The structure and evolution of the strategic management field: A content analysis of 26 years of strategic management research. International Journal of Management Reviews, 10(1), 123.

[4]. Galavan, R. J. (2015). Understanding Resources, Competences, and Capabilities in EU Common Security and Defence Policy. WORKING PAPER. Maynooth University, Ireland: Edward M Kennedy Institute for Conflict Intervention \& School of Business.

[5]. Garuba, A., 2013. Teachers and development projects in education Sector. A paper presented in 11th Biennial Conference of Internal Study Association. Lelden Netherlands. Available http://www./isatt.net/.

[6]. Gerhard Mmeidell, (2018). Norwegian Social Science Data Services. Norway: international publishers.

[7]. Grant, R.M. (2002). Contemporary Strategy Analysis: Concept, Techniques and Applications. 2nd Edition. Massachusetts: Blackwell.

[8]. Grimes, P. (2018). Economic and World history. Myths and Paradoxes, USA: Chicago University press.

[9]. Hair, J.,Black, W.C., Babin, B.J.,\& Anderson, R.E.(2010). Multivariate data analysis (7 $7^{\text {th }}$ ed). Upper Saddle River, New Jersey: Pearson education international.

[10]. Hanaysha, R. (2016). Applied Statistics from Bivariate Through Multivariate Techniques. Thousand Oaks, C.A. Sage.

[11]. Honke, J., \& Cuesta-Fernandez, I. (2017). A topographical approach to infrastructure: political topography, topology and the port of Dar Es Salaam. Environment and Planning D: Society and Space, 35(6), 1076-1095.

[12]. Igba, D.I., 2015. Indispensability of agricultural input materials in the implementation of rice irrigation scheme programmes. Journal of Arts and Social Science Education, 1(1): 24-34.

[13]. Immyxail, S. \& Takahashi, Y. (2015). The Effect of Firm Resources on Performance of Male and Female Headed Firms: The Case of Lao Micro Small and Medium Sized Enterprises .International Journal of Development.6, 63-90.

[14]. Ishengoma, (2012). Cost-sharing Project and Participation in Higher Education in sub-Saharan Africa: The case of Tanzania: Dar es Salaam press .

[15]. Jiang, C.,wan, Y.,\& Zhang., A. (2017) internalization of port congestion : strategic effects behind shipping line delays and implication for terminal charges and investment. Marine Policy \& Management, 44(1)112-130.

[16]. Joseph, S.O. \& Y.P. Olatunde, 2011. Provision of facilities and achievement of affordable house projects in South Africa. African Journal of Social Science, 7(7): 1-18. Retrieved from www.cuea.edu/.

[17]. Kadzara, C.M., 2016. Use of Science and business study in project management instructional technologies in Tanzania, (unpublished doctoral dissertation). Virginia Polytechnic Institute and State University: USA. 


\section{International Advanced Research Journal in Science, Engineering and Technology}

Vol. 8, Issue 5, May 2021

\section{DOI: $10.17148 /$ IARJSET.2021.8507}

[18]. Kaplan, R.S. \& Norton. (2016). The Balance Score Card: Translating strategy into Action. Harvard Business School Press, Boston MA.

[19]. Kendell, R. (2013). Distinguishing between the validity and reliability of psychiatric Diagnoses. The United State of America: Macmillan publishing company.

[20]. Kothari, C. K. \& Garg, G. (2012). Research methodology: Methods and techniques (3 ${ }^{\text {rd }}$ edition). New Delhi: New Age International Limited Publishers.

[21]. Kraaijenbrink, J., Spender, J., \& Groen, A. (2010). The resource-based view: a review and assessment of its critiques. Journal of Management , $36,349-372$.

[22]. Laurent, T. K. (2017). Factors affecting Airports Construction Projects in Tanzania. Dar es Salaam: Open University of Tanzania.

[23]. Lewis \& Thornhill (2017). Business Statistics for Contemporary Decision Making (Fourth Wiley Student Edition for India). India: Wiley publisher New Delhi.

[24]. Magasi, C., Tonya, E., \& Kapaya, S. M. (2020). Effects of Internal Resources and Capabilities on the Survival of Family - Owned Manufacturing Firms in Dar es Salaam, Tanzania. African Journal of Applied Research , 6 (1), 76-90.

[25]. Malhotra, N.K. \& Dash, L. (2017) Marketing Research and Applied Orientation. New Delhi: Pearson.

[26]. Mark, L., LengNick, H., Cynthia, A., Hall, L., Androde, L.S. \& Drake, B. (2018). Strategic Human Resource Management: The Evolution of the Field. Human Resource Management Review, 64 - 85.

[27]. Martin, v. (2016). Managing Project in Human Resources Training and Development. London: British library press. 